\title{
The effect of an oral glucose load on serum free amino acid concentrations in children before and after treatment for kwashiorkor
}

\author{
By R. F. GRIMBLE AND R. G. WHITEHEAD* \\ MRC Child Nutrition Unit, Mulago Hospital, Kampala, Uganda
}

(Received 2 Fune 1970-Accepted 17 August 1970)

\begin{abstract}
1. The mechanisms by which an oral dose of glucose can stimulate the uptake of essential amino acids from serum was found to be operative even in children with severe, untreated kwashiorkor.

2. Although the percentage fall in the concentration of the essential amino acids in response to glucose was the same before and after treatment, the absolute fall was greater on discharge. The results indicated that the magnitude of this fall might depend on the initial fasting concentration of each individual amino acid.

3. These results have been discussed on the basis of possible long-term pathological effects of a distorted serum amino acid pattern typified by low concentrations of valine, leucine and threonine. The protein-sparing action of carbohydrate, achieved by the preferential synthesis of muscle protein in response to insulin secretion, might be less effective because of substrate limitation.

4. Of the non-essential amino acids, the concentrations of alanine and glycine also fell markedly before treatment, but this did not occur on discharge. The significance of this difference is also discussed.

5. The results also indicate that slightly high, spurious amino acid ratios can be obtained if a child is given a drink containing sugar before a blood sample is taken.
\end{abstract}

The administration of a glucose load, either to man or experimental animals, causes a reduction in the concentrations of some of the serum-free amino acids (Schmidt \& Eastland, 1935; Munro, 1956; Manchester \& Young, 196I). The amino acids lost from the serum are preferentially deposited in muscle tissue under the mediation of insulin (Harris \& Harris, 1947; Munro, 1956). The amounts of the individual essential amino acids which disappear are in approximately the proportions in which they are found in 'high-quality' proteins such as muscle and egg (Lotspeich, 1949; Munro \& Thomson, 1953). From these and similar results it has been postulated that the amino acids which enter muscle are immediately incorporated into protein, a conclusion strengthened by subsequent isotope studies (Munro, Black \& Thomson, 1959).

On the basis of this evidence, Swendseid, Tuttle, Drenick, Joven \& Massey (1967) decided to find out if different nutritive conditions might alter the response to glucose ingestion. If the disappearance of serum-free amino acids is linked to protein synthesis in the muscle it was reasoned that protein deficiency might well affect this reaction.

The experimental subjects of Swendseid et al. (1967) were elderly volunteers given I4 $\mathrm{g}$ nitrogen and then $3.5 \mathrm{~g}$ nitrogen contained in isocaloric diets. Although the subjects went into negative nitrogen balance for as long as $\mathrm{I}$ month on the latter

* Requests for reprints to R. G. Whitehead, MRC Child Nutrition Unit, PO Box 6717, Kampala, Uganda. 
diet, no change in the response to glucose was detected. The authors suggested, however, that there might have been some effect if their subjects could have been more severely malnourished.

The present paper reports an investigation of this possibility in a small group of Ugandan children with severe kwashiorkor, before and after successful treatment.

\section{METHODS}

The five children studied all suffered from oedematous malnutrition (kwashiorkor). They varied in age from 12 to 25 months and were treated according to the schedule described by Staff (1968).

On admission and immediately before discharge the procedure was as follows. A sample of venous blood was taken after an overnight fast, after which an oral dose of $2.5 \mathrm{~g}$ D-glucose $/ \mathrm{kg}$ body-weight was given to each child. Further blood samples were taken 30,60 and $120 \mathrm{~min}$ later. The blood was allowed to clot for $10 \mathrm{~min}$ and the serum was separated by centrifugation.

To $250 \mu \mathrm{l}$ of each serum sample was added an equal volume of I $\%(w / v)$ sodium fluoride to arrest glycolysis. The samples were then temporarily stored at $-20^{\circ}$ until blood sugar was estimated in a Technicon AutoAnalyzer using the potassium ferricyanide, potassium ferrocyanide oxidation-reduction reaction ('Technicon method file $\mathrm{N}-2 \mathrm{~b}$ ). 'Total protein and albumin concentrations in the serum were assayed simultaneously by the automated micro-method described by Coward, Sawyer \& Whitehead (1970).

The serum-free amino acids were estimated in a further $25^{\circ} \mu \mathrm{l}$ of serum in a Technicon TSM I Amino Acid AutoAnalyzer by the modified method described by Grimble \& Whitehead (1970a). Although separated during the chromatographic procedures, quantitative values for glutamic acid, glutamine, cystine and proline are not recorded for reasons previously described (Grimble \& Whitehead, r970c). Tryptophan was not detected in serum by this method.

\section{RESULTS}

The ingestion of $2.5 \mathrm{~g}$ glucose $/ \mathrm{kg}$ body-weight caused a rise in the fasting concentrations of blood sugar of all the children, both on admission and at the end of treatment, although the hyperglycaemic response tended to be of a slightly more 'diabetic' type at the first investigation. The mean rises in blood sugar and standard errors at 30,60 and I20 min after glucose administration were $85 \pm 19,88 \pm 28$ and $40 \pm 32 \mathrm{mg} /$ I $00 \mathrm{ml}$ on admission, and $95 \pm 29,42 \pm 10$ and $35 \pm 1 \mathrm{I} \mathrm{mg} / 100 \mathrm{ml}$ at discharge. This is an observation frequently encountered in children with kwashiorkor in Uganda and the causes have been studied by Hadden ( 1967 ).

In spite of these small differences in hyperglycaemic response, the maximum effects of the glucose load on amino acid concentration occurred after the same period of time before and after treatment. Table I shows this maximal effect for the essential and 'semi-essential' amino acids, 120 min after glucose administration, and for the nonessential ones after $60 \mathrm{~min}$. The essential amino acid group consisted of valine, leucine, isoleucine, threonine, tyrosine plus phenylalanine, lysine and methionine; the 
semi-essentials were histidine and arginine, and the non-essentials, glycine, alanine, serine and aspartic acid. The fasting concentrations of the essential amino acids were typically low at the start of the study but had recovered to normal values by the end of treatment. The absolute fall in concentration of the essential amino acids in response to glucose was significantly greater on discharge than at admission, indicating that the magnitude of this fall might depend on the initial concentration. The mean percentage change was, however, the same.

Table r. Total fasting levels, maximal changes in serum essential and semi-essential amino acid concentrations in the serum of children undergoing treatment for kwashiorkor, measured 120 min after a glucose load, and changes in non-essential amino acid concentration after 60 min (for details see p. 254)

\begin{tabular}{|c|c|c|c|c|c|c|c|c|c|c|c|}
\hline \multirow{3}{*}{$\begin{array}{l}\text { Amino } \\
\text { acids }\end{array}$} & \multicolumn{6}{|c|}{ On admission } & \multicolumn{5}{|c|}{ On discharge } \\
\hline & \multicolumn{2}{|c|}{$\begin{array}{c}\text { Fasting } \\
\text { level } \\
(\mu \text { moles } / 1)\end{array}$} & \multicolumn{2}{|c|}{$\begin{array}{l}\text { Change in } \\
\text { concentration } \\
(\mu \text { moles } / 1)\end{array}$} & \multicolumn{2}{|c|}{$\begin{array}{c}\text { Change } \\
(\%)\end{array}$} & \multicolumn{2}{|c|}{$\begin{array}{c}\text { Fasting } \\
\text { level } \\
(\mu \text { moles } / 1)\end{array}$} & \multicolumn{2}{|c|}{$\begin{array}{l}\text { Change in } \\
\text { concentration } \\
(\mu \text { moles } / 1)\end{array}$} & $\begin{array}{c}\text { Change } \\
(\%)\end{array}$ \\
\hline & Mean & $\mathrm{SE}$ & Mean & $\mathrm{SE}$ & Mean & SE & Mean & $\mathrm{SE}$ & Mean & SE & Mean \\
\hline & 375 & 69 & -88 & 23 & -23 & 6 & & 34 & -273 & $22 *$ & -26 \\
\hline & & 40 & -29 & 26 & -5 & 19 & & & -45 & $2 \mathrm{I}$ & -22 \\
\hline on-essential & 765 & $8 I$ & $-2 I I$ & $2 \mathrm{I}$ & -27 & 2 & 893 & 66 & +56 & $24^{* *}$ & +6 \\
\hline
\end{tabular}

* Fall in concentration significantly greater than on admission by the paired $t$ test $(P<0.05)$.

** Fall in concentration significantly less than on admission by the paired $t$ test $(P<0.01)$.

The non-essential amino acids gave a completely different response. On admission, their total concentration fell like that of the essentials; on discharge this did not occur, and in fact the concentration tended to rise.

The semi-essential amino acids responded in an apparently erratic manner, which was demonstrated by the high standard error for these compounds. In one of the children, on admission, glucose produced a small rise in concentration, whereas in the others a fall occurred. There was also considerable scatter in the initial fasting concentrations of these amino acids.

Table 2 gives the values for the individual amino acids. The amino acids that were most sensitive to the glucose load were valine, leucine and threonine; lysine, methionine, isoleucine, phenylalanine and tyrosine were less affected. This pattern of change is in good agreement with that found in previous studies. In general, the fall in absolute concentration of the separate essential amino acids was higher on discharge although, because of the scatter of results, this was only statistically proven for valine; the percentage change was not different on discharge.

One of the most interesting differences between the effects of glucose given on admission and on discharge was found for the non-essential amino acid, alanine. Though the concentration of alanine fell in all patients on admission, it rose on discharge. This difference was highly significant. Glycine concentration followed a similar pattern, although on recovery in only three of the five patients was there a rise. Serine and aspartic acid concentrations fell in both circumstances but rather less on discharge. 
Measurements of total protein and albumin in each serum sample demonstrated that the changes in amino acid concentration could not be accounted for by generalized fluctuations in plasma concentration.

Table 2. Fasting levels and maximal changes in concentration of different amino acids in the serum of children undergoing treatment for kwashiorkor after a glucose load (for details see $p$. 254)

\begin{tabular}{|c|c|c|c|c|c|c|c|c|c|c|c|c|}
\hline \multirow[b]{3}{*}{$\begin{array}{l}\text { Amino } \\
\text { acid }\end{array}$} & \multicolumn{6}{|c|}{ On admission } & \multicolumn{6}{|c|}{ On discharge } \\
\hline & \multicolumn{2}{|c|}{$\underbrace{\begin{array}{c}\text { Fasting } \\
\text { level } \\
(\mu \text { moles } / 1)\end{array}}$} & \multicolumn{2}{|c|}{$\begin{array}{l}\text { Change in } \\
\text { concentration } \\
(\mu \text { moles } / 1)\end{array}$} & \multicolumn{2}{|c|}{$\begin{array}{c}\text { Change } \\
(\%)\end{array}$} & \multicolumn{2}{|c|}{$\begin{array}{c}\begin{array}{c}\text { Fasting } \\
\text { level } \\
(\mu \text { moles } / 1)\end{array} \\
\overbrace{}^{\text {lon }}\end{array}$} & \multicolumn{2}{|c|}{$\begin{array}{c}\begin{array}{c}\text { Change in } \\
\text { concentration } \\
(\mu \text { moles } / 1)\end{array}\end{array}$} & \multicolumn{2}{|c|}{$\begin{array}{c}\begin{array}{c}\text { Change } \\
(\%)\end{array} \\
\overbrace{}^{(\%)}\end{array}$} \\
\hline & & & & & Mean & SE & Mean & $\mathrm{SE}_{\mathrm{SE}}$ & Mean & $\overbrace{\mathrm{SE}}$ & Mean & SE \\
\hline Valine & 60 & 7 & -16 & 3 & -29 & 6 & 257 & 13 & -86 & $9^{* *}$ & -33 & 2 \\
\hline Leucine & 88 & 25 & -32 & I6 & -35 & 9 & 136 & 19 & -56 & I 5 & -30 & 7 \\
\hline Isoleucine & 27 & 3 & -3 & 7 & $\begin{array}{l}-10 \\
0\end{array}$ & 23 & 85 & 14 & -24 & I5 & -10 & 14 \\
\hline Threonine & 45 & I3 & $-\mathrm{r} 5$ & I I & -22 & I 5 & 140 & 18 & -43 & 8 & -30 & 2 \\
\hline $\begin{array}{l}\text { Phenylalanine } \\
\text { plus tyrosine }\end{array}$ & 77 & 12 & -9 & 6 & -14 & IO & 202 & $3 \mathbf{I}$ & -56 & I 5 & -26 & 6 \\
\hline Lysine & 68 & 20 & -13 & I I & -10 & I6 & 105 & 22 & $-I$ & I4 & -9 & I 5 \\
\hline Methionine & II & 3 & -3 & 3 & -8 & 5 & $2 I$ & 4 & -6 & 5 & -10 & 18 \\
\hline Argini & 76 & 25 & -24 & 17 & -12 & I8 & 149 & $30^{\circ}$ & -32 & 24 & -22 & I3 \\
\hline Hist & 88 & 18 & -5 & 16 & -5 & 29 & 103 & 20 & -14 & II & -8 & \\
\hline Glyci & 284 & 23 & -87 & IO & $-3 I$ & 3 & 280 & I6 & +3 & $2 I$ & $+I$ & \\
\hline Alani & 264 & 32 & -54 & 16 & -20 & 4 & $35 \mathrm{I}$ & 47 & +72 & $22 * * *$ & +20 & \\
\hline Serine & 149 & 16 & -45 & 12 & -17 & 4 & 202 & I 3 & -16 & 8 & -22 & \\
\hline Aspartic acid & 68 & $x_{7}$ & -27 & 7 & -40 & 5 & 60 & 8 & -3 & 2 & -2 & \\
\hline
\end{tabular}

* Fall in concentration significantly greater than on admission by the paired $t$ test $(P<0 \cdot 01)$.

*** Rise in concentration significantly greater than on admission by the paired $t$ test $(P<0.001)$.

\section{DISCUSSION}

The results have demonstrated that the sequence of metabolic reactions initiated by a glucose load, which leads to the removal of essential amino acids from the blood plasma under the influence of insulin, is operative even in children with severe kwashiorkor. From one point of view this finding was, perhaps, not surprising. Hadden (1967) measured plasma insulin concentrations in Ugandan children with severe kwashiorkor, using the radio immunoassay technique, and found normal and, in some instances, even high concentrations of the hormone. If, however, the disappearance of serum amino acids is directly linked with the synthesis of protein by muscle, as implied by many authors (Harris \& Harris, 1947; Lotspeich, 1949; Munro, 1956; Swendseid et al. ${ }^{967}$ ), it would mean that the mechanisms for protein synthesis are maintained in the muscle even in very severe protein deficiency. Thus our findings confirm the conclusions of Swendseid et al. (1967) that any biochemical loading test, for assessing nutritional status in children or adults, based on a failure of this mechanism is unlikely to be of any practical value.

In the study of Swendseid et al. (1967), not only was the pattern of disappearance of the essential amino acids the same in normal and protein-deprived adults, but the absolute quantities which disappeared were also very similar. This was clearly not so 
in our study. In these children, the absolute amount of an amino acid which disappeared from the serum seemed to depend on the fasting concentration; the concentrations of many of the essential amino acids were abnormally low on admission and there was, consequently, very little uptake of these amino acids. In the subjects of Swendseid et al. (1967), however, the serum amino acid pattern was only slightly distorted and little difference in amino acid uptake would be expected on the two diets used by Swendseid et al. It was interesting though that, of all the amino acids, valine was the one in which the uptake in response to glucose was reduced the most on the low-protein intake.

The present results may shed further light on the pathological consequences of a distorted serum amino acid pattern. This biochemical abnormality can be present for many months before a child is precipitated into kwashiorkor. Munro (1964) has reviewed the mass of information which indicates that dietary carbohydrate has a specific metabolic role, apart from the more general property of supplying calories, through its protein-sparing action. By stimulating the passage of amino acids to muscle rather than liver, less amino nitrogen is lost through catabolism to urea. Clearly this protective mechanism must be particularly important for children living on lowprotein, high-carbohydrate foods. If, however, this process is limited by the concentration of the essential amino acids in the serum, it could become progressively less effective as the serum concentrations of amino acids such as valine became gradually reduced, eventually to values as low as one-fifth to one-tenth normal. The reasons why the concentrations of the essential amino acids become so low in kwashiorkor has been discussed elsewhere (Grimble \& Whitehead, I970 b, c).

In previous studies various authors have furnished evidence to support the hypothesis that the pattern of amino acids leaving the serum is constant and similar to that in muscle protein. We have made no attempt to do this from our results since we considered that the degree of scatter for certain individual amino acids was too large. Indeed this criticism could be levelled at other sets of results, and reference was made to this fact in the early contribution of Harris \& Harris (1947), who showed that by no means all subjects exhibited exactly the same response to glucose. Swendseid et al. (1967) provided some valuable information on this point when they showed that obese subjects and people of more conventional stature given ketogenic diets showed a more variable pattern in their amino acid response to glucose. This finding might have some relevance for our results; children with kwashiorkor exhibit marked fatty infiltration of the liver and often have more subcutaneous fat than might be expected from their advanced state of malnutrition. Recovery is associated with mobilization of fat from the liver and this could have been the cause of some variability in the amino acid response to glucose. Disappearance of amino acids from the serum does not, by itself, prove uptake of amino acids by the muscle, although this assumption has been made in most investigations. It is possible that another reason for the variable response might be uptake of amino acids into other tissues or even to losses by excretion in the urine.

Swendseid et al. (1967) found no change in the values for total non-essential amino acids before and after the ingestion of glucose, and the individual amino acids gave 
a rather variable response, although alanine was usually elevated. This is what we found in our children studied after treatment, but the response on admission was quite different. All the non-essential amino acids recorded fell in concentration, particularly glycine and alanine. There is no obvious explanation for this phenomenon, but it is conceivable that in extreme protein deprivation even the so-called nonessential amino acids were in short supply and thus were taken up like essential amino acids before protein could be synthesized by the muscle under the influence of insulin.

The rise in serum alanine concentration after recovery following the glucose load might be related to the key role of this amino acid in gluconeogenesis; higher serum concentrations might result from a 'shutting off' of this mechanism (Felig, Owen, Wahren \& Cahill, 1969; Grimble \& Whitehead, 1970c).

The results also reveal a factor which could complicate the interpretation of the serum amino acid ratio (Whitehead, 1964). A high carbohydrate intake before a blood sample is taken, such as might be provided by a surreptitious soft drink, could cause a small fall in the denominator of the ratio, which consists principally of the branchedchain amino acids. In normal children a rise in the numerator could also occur because of an increase in glycine. This might result in a slight rise in the ratio. This is no problem if fasting samples are collected, but it is often difficult to ensure really fasting conditions in a survey. Luxuries such as bottled soft drinks are not habitually given to children in most developing countries but this could be a problem elsewhere.

We would like to thank Dr Michael Parkin, Dr Elizabeth Poskitt and Sister Frances Shaw and her nursing staff for supervising this study in the ward. We also acknowledge the technical assistance of Mr J. B. Kiwanuka and Mr F. N. Nkubihinda.

\section{REFERENCES}

Coward, D. G., Sawyer, M. B. \& Whitehead, R. G. (r970). Am. F. clin. Nutr. (In the Press.)

Felig. P., Owen, O. E., Wahren, J. \& Cahill, G. F. Jr (1969). F. clin. Invest. 48, 584.

Grimble, R. F. \& Whitehead, R. G. (1970a). In Technicon Quarterly. New York: Technicon Inc.

Grimble, R. F. \& Whitehead, R. G. (1970b). Lancet i, 918.

Grimble, R. F. \& Whitehead, R. G. (I970c). Br. F. Nutr. 24, 557.

Hadden, D. R. (1967). Lancet ii, 589.

Harris, M. M. \& Harris, R. S. (1947). Proc. Soc. exp. Biol. Med. 64, 47 I.

Lotspeich, W. D. (r949). F. biol. Chem. 179, I75.

Manchester, K. L. \& Young, F. G. (1961). Vitams Horm. I9, 95.

Munro, H. N. (1956). Scot. med. F. 1, 285 .

Munro, H. N. (1964). In Mammalian Protein Metabolism Vol. I, Ch. 1o [H. N. Munro and J. B. Allison, editors]. New York and London: Academic Press Inc.

Munro, H. N., Black, J. G. \& Thomson, W. S. T. (1959). Br. F. Nutr. 13, 475.

Munro, H. N. \& Thomson, W. S. T. (r953). Metabolism 2, 354.

Schmidt, E. G. \& Eastland, J. S. (1935). F. Lab. clin. Med. 20, r.

Staff, T. H. E. (1968). E. Afr. med. F. 45, 399.

Swendseid, M. E., Tuttle, S. G., Drenick, E. J., Joven, C. B. \& Massey, F. J. (I967). Am. F. clin. Nutr. 20, 243.

Whitehead, R. G. (I964). Lancet i, 250. 